\title{
My Foreign Self as Privileged \\ Outsider: Differing Lines for Marginalization and Inclusion of Swiss Living Abroad
}

\author{
Aldina Camenisch and Seraina Müller
}

\begin{abstract}
Based on ethnographic field research in Northern Europe and China amongst Swiss nationals, this paper explores how such relatively privileged migrants negotiate their identities with respect to their society of origin and their host societies. By doing so, they participate in and produce a variety of discourses of inclusion and demarcation that are often ambiguous and fleeting. In this context, the paper concludes with an outline of those 'third positions', which are liminal by being neither fully 'in' nor 'out', and which draw into question any spectra for expanding inclusion. These positions develop from past and present experiences of our respondents as simultaneous insiders and outsiders, but are importantly shaped by relative social privilege as opposed to political or economic need.
\end{abstract}

\section{Keywords}

migration - mobility - national and cultural identity - intersectionality - transnationalism - politics of inclusion - foreign privilege

\section{$1 \quad$ Introduction}

Based on an on-going ethnographic research project among Swiss - who are voluntary and thus relatively privileged migrants - in both Northern Europe and China, this paper explores in the first two chapters our respondents' negotiations of belonging with respect to Switzerland and their host societies. In the third chapter, we elaborate on 'third positions' that emerge from past and present experiences as in- and outsiders. 
The data collection for this project took place over a period of two years. 32 people, 21 men and 11 women, living in eight major Mainland Chinese cities, in Hong Kong, and in Switzerland were interviewed as well as 35 people, 16 men and 19 women, currently residing in Denmark, Finland, Norway, and Sweden.*

\section{Negotiating Belonging in Northern Europe and China}

\subsection{Swiss Migrants in China: Privileged Outsiders}

When describing their feelings about living in China, some of our respondents explained that their involvement with China had started in their childhood or youth, while they were still living in Switzerland, and thus evolving around imaginaries of China. ${ }^{1}$ The majority of our interview partners, however, came to China for the first time with little prior involvement with the country. For them, China was the exotic 'other', a place that attracted them because they knew nothing about it and which therefore promised the adventure and challenge they were looking for.

Now that they actually live in China, whether the respondents are those respondents with a long-standing fascination or those without, their negotiations of belonging are ambivalent. Many interview partners emphasise that they strive towards understanding for and a certain adaption to their Chinese host society. Moreover, most see themselves in the right place on the level of their daily lives. Yet, none of them feels that he or she belongs fully in the Chinese society.

One of the most important reasons for this is - as all our respondents unequivocally observe - that the discursive demarcations between insiders and outsiders, the Chinese and the foreigners, ${ }^{2}$ are immutable and cannot be crossed. ${ }^{3}$ As the 'other' in the form of a 'white', 'western', ${ }^{4}$ and Swiss foreigner in China, they are ascribed and act out multi-faceted positions that are rooted

* The authors thank Emma Hill and David Bell for their helpful comments on earlier versions of this chapter.

1 Arjun Appadurai, 'Disjuncture and Cultural Difference in the Global Cultural Economy.' Theory, Culture and Society 7 (1990): 295-310; Noel B. Salazar, "The Power of Imagination in Transnational Mobilities.' Identities: Global Studies in Culture and Power, 18.6 (2011): 576-598.

2 Waiguoren in Chinese.

3 For a more detailed discussion of immigration in China see Frank N. Pieke, 'Immigrant China.' Modern China 38.1 (2012): 40-77.

4 Anne-Meike Fechter, 'The 'Other' Stares Back. Experiencing Whiteness in Jakarta.' Ethnography 6.1 (2005): 87-103. 


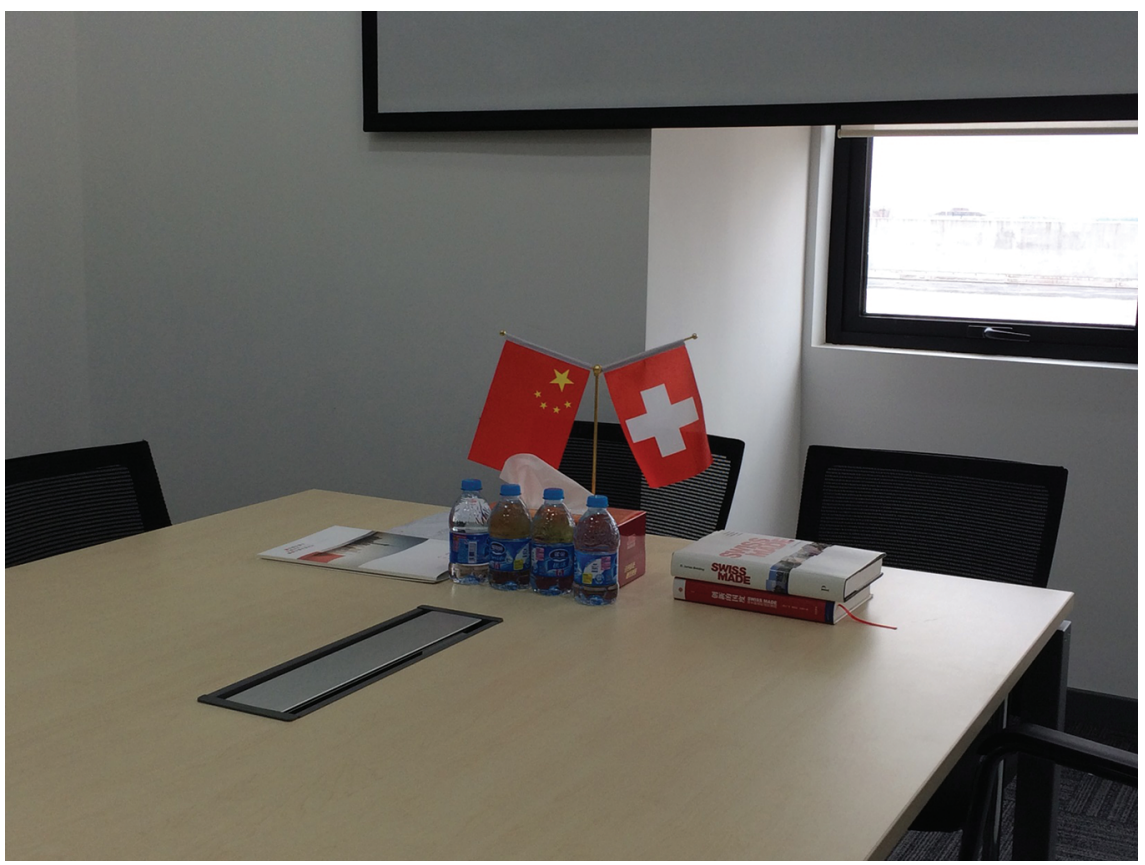

FIGURE 3.1 Meeting room at a Sino-Swiss business consultancy in Shanghai PHOTO TAKEN BY ALDINA CAMENISCH IN FEBRUARY 2015

in (post-) colonial identity politics and power regimes, in imaginaries of economic and social progress, as well as in notions of physical attractiveness. ${ }^{5}$

Alice, 32, manager: 'You say you are Swiss, it's a legitimacy of quality, of trustfulness. I'm supposed to be someone honest, someone well educated, I mean, you know. And someone wealthy. [...] It gives a legitimacy on a few aspects of personality that I don't have to justify.'

5 Gender plays a crucial role, too, and will need special attention in further analysis. As for the marker of race, it is interesting to note that two of our interview partners with 'East Asian' physical features experienced their social position differently from all the other interview partners with 'white', 'Caucasian' looks that feel marked as 'westerners'. One, who is Swiss with Chinese parents, describes how Chinese people would count him as (overseas) Chinese rather than as foreigner. Another interview partner grew up in Switzerland as an adopted child from Korea and referred to himself as 'a banana, yellow outside, white inside'. He describes, how most Chinese would take him for a Chinese from his looks and he feels that due to his external resemblance, it is easier for him to relate to Chinese people than for 'white' foreigners.

6 Interview conducted on February, 3rd, 2015, in Shanghai, China. Original quote. 
This contrasts strongly with the - in itself highly disputable and conflictive notion of the gradual integration of foreigners from out- to insiders that has been the guiding principle for dealing with immigration in the Swiss context. Whereas some accordingly imagined themselves 'integrated' into China before they moved, none holds this prospect anymore.

This results in marginalized, yet privileged positions that enable to exploit specific opportunities. Being a foreigner, according to our interview partners, liberates them of manifold social and economic obligations that Chinese individuals face. Hence, instead of gradually 'integrating', many interview partners describe, how after a long period of adaptation, they are now gradually 'rewesternizing' in order to succeed professionally as well as to (re-) gain a fitting, socially acknowledged identity:

Sarah, 28 , project manager and student: But I realize that I have to reinforce the western part, in the sense that I should make more western friends again. [...] I sometimes feel that I have been involved too deeply with Asians. And that I have adapted some attitudes that are not necessarily beneficial. For instance, that I feel under much pressure in terms of $\mathrm{CV}$, career, because I study. That I have lost the relaxed attitude I used to have. [...] Stuff like that, which gives you the pressure that you don't fit in anymore. ${ }^{7}$

On the other hand, in our respondents' perception, as a foreigner, certain areas of economic, social and political participation remain inaccessible and they expect little protection by the Chinese authorities in case of legal problems. For some, this situation results in a feeling of vulnerability.

Moreover, in many interviews, their half insider-half outsider position concurs with a persisting 'otherness' and exoticism of the Chinese environment, which is seen as providing a stimulating ambiguity of belonging:

7 Interview conducted on December, 5th in Guangzhou, China. The interview was held in German and the quote was translated by Aldina Camenisch. Original quote in German: 'Ich merke, dass ich den westlichen Teil wieder verstärken sollte, im Sinne von, dass ich wieder mehr westliche Freunde haben sollte. (...) ich habe manchmal das Gefühl, ich bin wie fast zu, ich habe viel zu viel mit Asiaten zu tun gehabt. Und von dem her auch gewisse Sachen angenommen, die vielleicht nicht unbedingt gut sind. Eben, dass ich zum Beispiel auch so mega Stress habe wegen CV, wegen Karriere, wegen dem Studieren. Dass ich quasi so ein wenig die Gelassenheit verloren habe, die ich früher hatte. (...) Und solche Sachen, dass man so Stress bekommt, dass man nicht rein passt.' 
Alice: I also like that now in China, I know people. Because if I go to buy the bread ... they recognize me, I recognize them. So we are, I feel close to them. But it is still exotic to me. So this is a feeling I really like. ... This is something that I can add to my life all the time. Non-stop, I would say. ${ }^{8}$

In accordance, belonging in China is often negotiated against a background of temporality and indefiniteness. This shows clearly in the way most interview partners talked about their stay in China as temporary, considering to move to other places, and eventually, but not necessarily, also back to Switzerland.

However, lines of demarcation are not only drawn between Chinese and foreigners, but also with respect to other foreigners. Most of our respondents describe themselves as relatively well-adapted, open-minded and skilled. As their counterparts, they draw the images of the ignorant and often undeservedly privileged corporate expatriates, and the western 'losers', who thanks to their looks rather than their professional skills, are able to make a living by working in typical 'foreigner jobs'?

\subsection{Swiss Migrants in Northern Europe: Neither in Nor Out}

Many of our respondents living in Northern Europe blend in easily with the local society in terms of physical appearance and are thus often not recognised as foreigners at first sight. As was often discussed in our interviews, the lines of demarcation are subtler. One of them is the language.

Esther, 55, farmer: 'Even after so many years living here, I still get the friendly-meant question "Where are you from?" whenever I open my mouth. I am absolutely fluent in Norwegian, but I will always keep my Swiss accent. This is sometimes very frustrating.' ${ }^{10}$

8 Interview conducted on February, 3rd, 2015, in Shanghai, China. Original quote.

9 Pei-Chia Lan, 'White Privilege, Language Capital and Cultural Ghettoisation: Western High-Skilled Migrants in Taiwan.' Journal of Ethnic and Migration Studies 37.10 (2011): 1169-1963; James Farrer, “"New Shanghailanders" or "New Shanghaiese”: Western Expatriates' Narratives of Emplacement in Shanghai.' Journal of Ethnic and Migration Studies 36.8 (2010): 1211-1228.

10 Interview conducted on January, 25th, 2014, outside of Oslo, Norway. The interview was held in German and the quote was translated by Seraina Müller. Original quote in German: 'Obwohl ich schon so viele Jahre hier wohne, werde ich immer noch die wohl nett gemeinte Frage gefragt: "Woher kommst du?", sobald ich meinen Mund öffne. Ich sprech absolut fliessendes Norwegisch, aber ich werde meinen Schweizer Akzent für immer behalten. Manchmal ist das ziemlich frustrierend.' 
Here, language is much more than just the exchange of information. In fact, it is part of the appearance of identity and social hierarchy. ${ }^{11}$

Even though most of our interview partners are fluent in the language of their country of arrival, most of them never manage to lose their foreign accents totally, which unmasks them immediately as somebody who was not born in the host country. This creates a dilemma. On the one hand, there is this feeling of being well embedded in the new heimat, home, combined with a strong sense of belonging. On the other hand, the fact of being recognised as a foreigner whenever using the local language seems to create frustration and alienation.

However, using a different language than the mother tongue can as well result in a new and unexpected experience.

Veronika, 32, consultant: 'In Swedish, everybody uses the Du, you. Nobody uses the polite form. Right in the first weeks here in Sweden, I realized, that new relationships, especially in business, start on a different level than in Switzerland. I think that there is a connection between the form of language and the way people encounter each other.'12

In accordance with the observations in China, several of our interview partners state an emotional connection with or even romantic attraction to one of the Nordic countries prior to their migration experience.

Sandra, 40, language consultant: 'Already in my younger days, the Finnish language fascinated me. I don't really know why. My mother thinks it has something to do with the TV series about Lapland. Anyway, I was always interested in languages. I learned Italian, Russian and later Finnish. It was somehow exotic.'13

11 Monika Heller, Paths to Post-Nationalism. A Critical Ethnography of Language and Identity (Oxford: University Press Inc, 2011).

12 Interview conducted on May, 10th, 2015, Stockholm, Sweden. The interview was held in German and the quote was translated by Seraina Müller. Original quote in German: 'Auf Schwedisch sind sich ja alle per "Du“ - man verwendet keine Höflichkeitsform. Gleich in den ersten Wochen hier in Schweden ist mir aufgefallen, dass neue Begegnungen, insbesondere im Beruf, auf einer anderen Ebene beginnen als in der Schweiz. Ich glaube, dass es ein Zusammenhang zwischen der Sprachform und der Begegnungsform gibt.'

13 Interview conducted on June, 17th, 2014, Helsinki, Finland. The interview was held in German and the quote was translated by Seraina Müller. Original quote in German: 'Die Finnische Sprache hat mich schon immer fasziniert. Ich weiss nicht warum. Meine Mutter meint, das hängt zusammen mit einer TV-Serie über Lapland. Sie meinte, das komme daher. Ich war schon früh interessiert an Sprachen. Italienisch, Russisch. Und ich lernte dann Finnisch. War irgenwie exotisch...' 
Again, language remains crucial in Sandra's life. Having both a German and a Swiss background, she is often torn between the different languages and dialects she wishes to speak with her own children. This hinders her somehow to fully engage with the local context; always feeling that one of her languages is missing.

Another influential aspect is the public discourse in which Swiss nationals are usually classified as 'good immigrants'. Often, there is a rather indifferent position towards Switzerland, dominated by stereotypical aspects such as the landscape and potential leisure activities in it, the political system, and Swiss cheese, chocolate, and watches. At the same time, there are rather negative notions around the reconcilability of family and working life in Switzerland, especially the comparably short parental leave, the extremely late introduction of women's suffrage, or the (in)famous Swiss banks. But generally, the perception of the Swiss as rather exclusive citizenship prevails. Iris, 22, stage designer, puts it this way: 'Some people even find it a bit exotic, that I am from Switzerland.'

Unlike the experiences of Swiss nationals in China, the negotiation of belonging in Northern Europe is initially less shaped by temporality and indeterminateness. Many of our respondents came to a Nordic country with the wish to stay, at least for some time. Several of them changed their country of residence due to love migration. ${ }^{14}$ This kind of migratory experience differs in many ways from other mobility forms. Among other things, it facilitates the first stage of arrival and grants access to local knowledge and networks.

However, we encountered several stories where changing family situations and crucial life events challenge the relationship with the (second) country of residence and renders one's situation unexpectedly transient.

\section{(Re-) Negotiating Switzerland from Afar}

A majority of our interview partners describes, how through the experience of living abroad, Switzerland as a country and as their place of origin has taken on different meanings.

Generally, Switzerland is the place of their mostly happy childhood memories which they call their heimat and where they locate their roots. While still living 'at home', however, being Swiss as well as the way our respondents had lived in Switzerland was by most simply taken for granted and not reflected much on.

14 Russell King, 'Towards a New Map of European Migration.' International Journal of Population Geography 8 (2002): 89-106. 


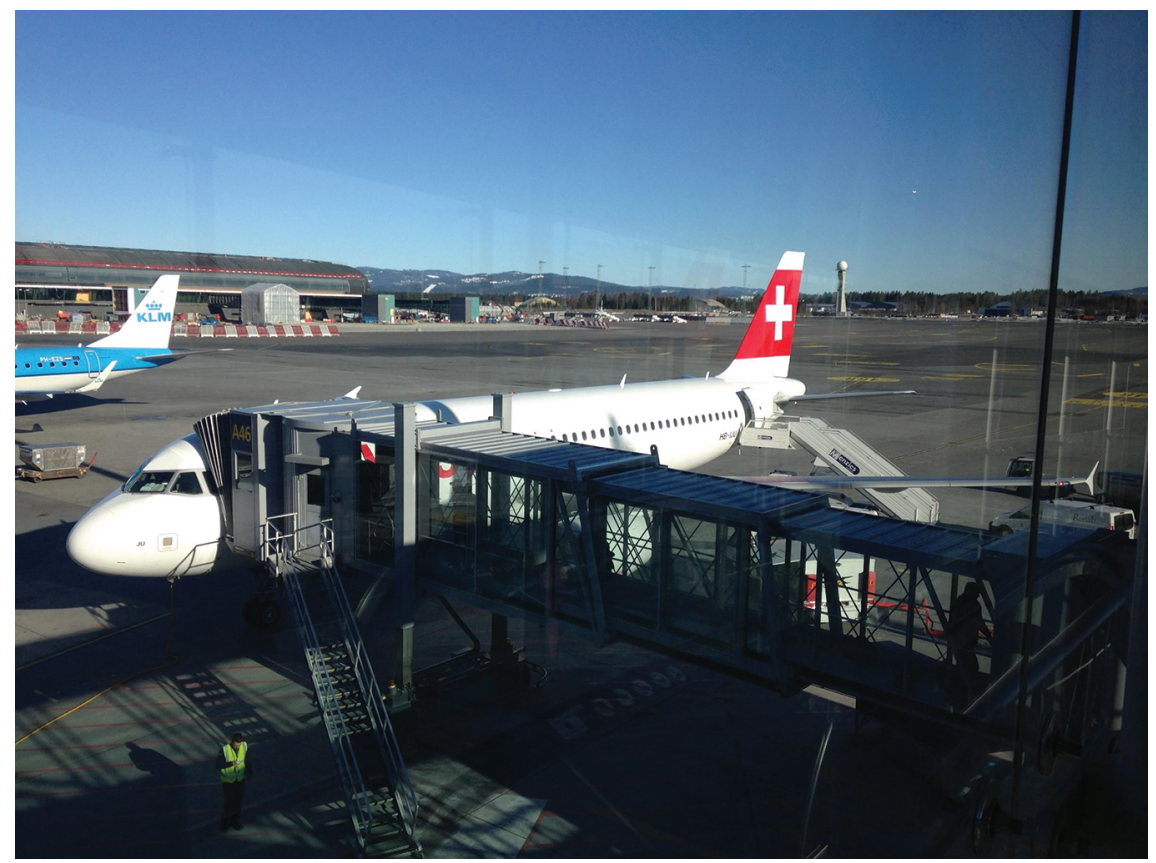

FIGURE 3.2 Departing flight from Oslo heading to Zurich

PHOTO TAKEN BY SERAINA MÜLLER IN MARCH 2015

Some of the interview partners also took a critical stance towards their Swiss environment, seeing it as an overregulated, uneventful place with a rather narrow-minded and complacent society. Hence, they felt that they would be happier elsewhere where they could lead a less predetermined, and more challenging life.

In our interview partners' narratives, the growing geographical and timely distance after migration leads to a revaluation of Switzerland and changes the relationship to it. Living abroad, respondents are all of a sudden constantly confronted with and sometimes reduced to their nationality and its assumed qualities. This triggers a reflection of their own identity and roots.

Additionally, the differing reality they encounter leads to a re-assessment of what they had experienced in and felt for Switzerland before. Even though those re-assessments remain multi-layered, and sometimes conflictive, overall, this 'bifocal' perspective sheds a rather positive light on their home country. ${ }^{15}$ Many respondents, especially those living in China, describe how they came

15 Sarah J. Mahler, "Theoretical and Empirical Contributions Toward a Research Agenda for Transnationalism.' Transnationalism from Below, eds. Michael P. Smith and Luis E. Guarnizo (London: Transaction Publisher, 1998), 64-102. 
to appreciate the high standard of living, the efficient infrastructure and state system, and the beautiful nature in Switzerland. This makes many aware of and grateful for their privileged background, and proud of being Swiss.

This enduring, and sometimes reinforced belonging happens not only on an emotional level but also manifests itself in active efforts to keep social relationships with friends and family in Switzerland, travel back frequently and stay up to date by reading or watching Swiss news. In addition, many respondents work in transnational settings and some also rent, or own apartments both in China or Northern Europe, and Switzerland.

Switzerland, therefore, not only appears as the place of our respondents' roots, but also as their 'safe haven'. For those without a transnational life, it remains the haven to fall back on if things do not work out abroad, or if personal situations and needs change.

Sarah: 'Switzerland is so beautiful. (laughs) Switzerland is great. (laughs) I sometimes even become absorbed in the thought that everything will be good if I went back to Switzerland. Everything will be fine. ... I think I couldn't live here without this feeling. ${ }^{\prime 16}$

Accordingly, we have observed how crucial life events such as becoming a parent, marriage, divorce or ageing have triggered a renewed reflection of belonging in Switzerland. Indeed, some interview partners with children have moved back or are considering doing so. Moreover, Switzerland is in unison referred to as a perfect place to spend one's retirement. For some, this brings about some truly ambivalent feelings.

Annalea, 45, mother of 6 children and student of education science: 'If I were to go back to Switzerland as retiree, I guess I would then get my pension from Norway. I don't know how the rules are. I absolutely see myself moving to Switzerland now. I wouldn't have a problem with that. But all depends on the children. I don't want to do an ego-trip going back to Switzerland and leave my kids behind. ${ }^{17}$

16 Interview conducted on December, 5th in Guangzhou, China. The interview was held in German and the quote was translated by Aldina Camenisch. Original quote in German: 'Ah, die Schweiz ist so schön. (lacht) Die Schweiz ist toll. (lacht) Ich verliere mich manchmal sogar im Gedanken, dass ich denke, wenn ich in die Schweiz zurück gehe, ist alles gut. Kommt alles gut. (...) Ich glaube, ohne dieses Gefühl könnte ich hier auch gar nicht so leben.'

17 Interview conducted on June, 10th, 2015, Sarpsborg, Norway. The interview was held in German and the quote was translated by Seraina Müller. Original quote in German: 'Wenn 
While Switzerland stands for one's safe haven and eventual return migration for many, time and distance have enhanced estrangement from 'home' for others. For them, if were they to leave China or Northern Europe, they'd rather move to another country than back to Switzerland, or a return would only be seen as a 'stopover'. Hence, leaving Switzerland was the first step in an increasingly mobile lifestyle.

Jan, 32, social anthropologist: 'Switzerland is more on the margins for me. Either here (in Norway) or towards another country. Switzerland would then rather serve as a stopover. To go there and see how it has developed during the years. And then a different country. Norway would be my backup. I like it better here.' ${ }^{18}$

This feeling of alienation relates to another common demarcation that is being upheld among many of our interview partners. Even though they refer to themselves as Swiss, they don't see themselves as the 'average person' back in Switzerland, who, according to them, lacks their own adventurous, energetic and entrepreneurial spirit as much as sophistication and open-mindedness.

\section{Neither Here Nor There - Manifestations of a 'Third State of Belonging'}

As we have described in the two preceding chapters, our interview partners' negotiations of belonging are shaped by rootedness as much as temporality, ambiguity and in-betweenness. In this chapter, we would like to conclude with an outline of these 'third positions'.

Some of the aspects of the Swiss migrants' negotiations of belonging described above, are mirrored in the notion of transnationalism. ${ }^{19}$ Whereas they

ich zurück in die Schweiz gehe als Pensionierte, dann hätte ich Pensionsgelder aus Norwegen. Ich weiss gar nicht, wie die Regeln sind. Ich kann mir gut vorstellen, jetzt in die Schweiz zu ziehen. Da hätte ich kein Problem. Aber es kommt auf die Kinder an. Denn ich will ja nicht als Egotrip zurück in die Schweiz und meine Kinder sind hier.'

18 Interview conducted on November, 12th, 2015, Oslo, Norway. The interview was held in German and the quote was translated by Seraina Müller. Original quote in German: 'Die Schweiz ist für mich eher etwas an der Aussenseite. Entweder hier oder in einem anderen Land. Die Schweiz wäre dann eher ein Zwischenhalt. Einmal dorthin zu sehen. Eventuell ein anderes Land und dann habe ich Norwegen als Back-up. Finde es hier besser.'

19 Nina Glick Schiller, Linda Basch, Cristina Szanton Blanc, 'From Immigrant to Transmigrant: Theorizing Transnational Migration.' Anthropological Quarterly 68.1 (1995): 48-63; 


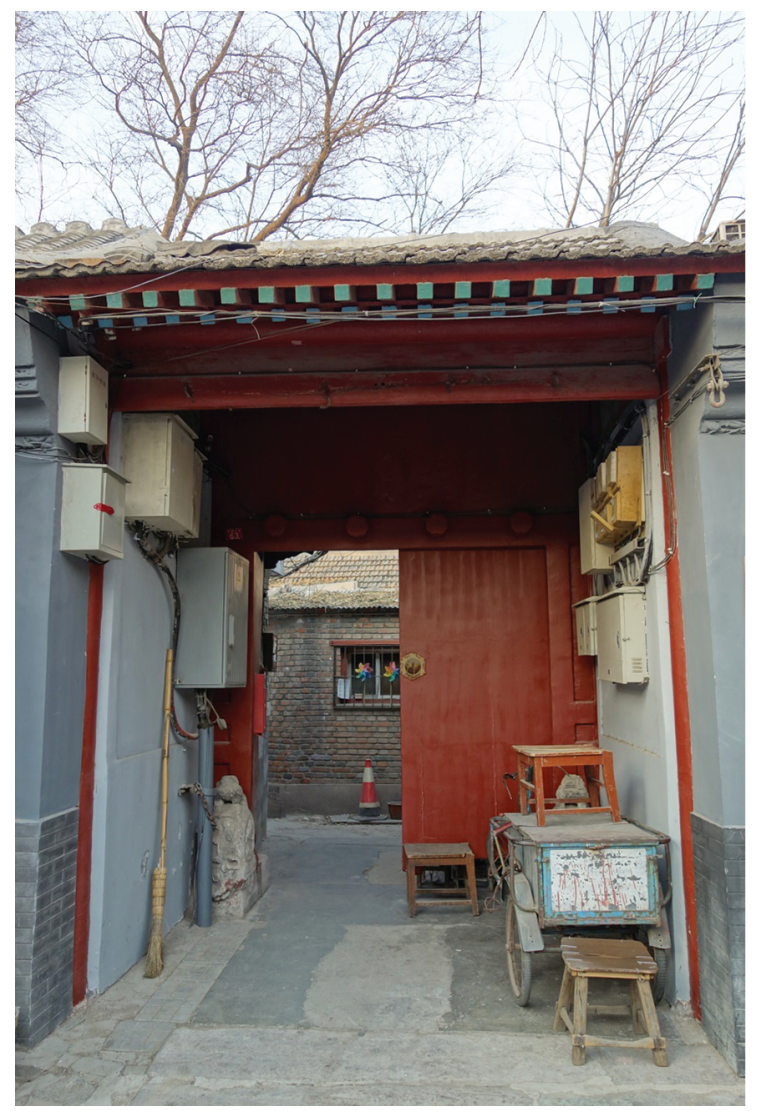

FIGURE 3.3 Entrance to a traditional Beijing courtyard (Hutong) in which a Swiss interview partner lives

PHOTO TAKEN BY ALDINA CAMENISCH IN JANUARY 2015

do feel 'at the right place' in their country of residence, Switzerland as the place of the roots and their home still holds a more or less important position in the personal 'geography of belonging' of respondents. Additionally, some also lead a transnational lifestyle through their work, living arrangements, or social relationships.

However, many experiences and feelings of our interview partners cannot be captured fully as a form of transnationalism. Rather, they seem to take on shapes that are more than solely rooted in or between two places. We have observed, how some of our respondents' personal 'geographies of belonging' have become multi-sited, situated in three, or more places, or even delocalised. Hence, as their life-courses are shaped by diversity and mobility, dichotomous and apparently durable notions of 'us' and 'them', and of clear-cut (trans-) national identities seem to apply no longer. Instead, their 'third states 
of belonging' have to be seen as changing landscapes shaped by notions of mobility and transience.

Remarkably, even though most of our interview partners have been living in Northern Europe and China for many years, many do not negotiate their life abroad as a migration experience but rather as a more flexible, potentially temporary state of mobility. In some migration trajectories, ending up in Northern Europe or China came about rather coincidentally, or as a result of a gradual process starting with travelling. Hence, lines commonly drawn between travel, mobility and migration dissolve, leading to 'mobile lifestyles.. ${ }^{20}$

Still, our interview partners are not directly equivalent to the so-called transnational elite subjects who move effortlessly without any need and wish to root themselves in specific local circumstances. ${ }^{21}$

Rather, in line with Yeoh and Huang, ${ }^{22}$ we argue that their experiences and considerations have to be understood as being shaped by specific social, economic and cultural contexts. Many of our interview partners correspondingly talked about how they have to a certain extent committed themselves to their Northern European or Chinese environment - but could also do so somewhere else.

This partly resonates in Hannerz' ${ }^{23}$ notion of cosmopolitan lifestyles, which enables people to 'go local' in different settings, finding one's way into new cultural contexts and developing corresponding competences. However, Hannerz focuses in our opinion too much on rather short-term 'hopping in and out' of a sociocultural pattern and distinguishes in a problematic way between 'cosmopolitans' and 'locals'.

Another concept which could be developed further to discuss our data, is that of the 'third culture kids'. Pollock and Van Reken ${ }^{24}$ describe third culture kids as being able to interact and connect with all sorts of socio-cultural contexts, but never fully immerge in them. Instead, they share a sense of belonging with people of similar background.

Luis E. Guarnizo, Michael P. Smith, 'The Locations of Transnationalism.' Transnationalism from Below, eds. Michael P. Smith and Luis E. Guarnizo (London: Transaction Publisher, 1998), 1-34; Steven Vertovec, Transnationalism (Abingdon: Routledge, 2009).

Scott A. Cohen, Tara Duncan, Maria Thulemark, 'Lifestyle Mobilites: The Crossroads of Travel, Leisure and Migration.' Mobilities 10.1 (2015): 155-172; Anthony Elliott, John Urry. Mobile Lives (Oxon: Routledge, 2010).

21 Leslie Sklair, The Transnational Capitalist Class (London: Blackwell 2001).

22 Brenda S. A. Yeoh, Shirlena Huang, 'Introduction: Fluidity and Friction in Talent Migration.' Journal of Ethnic and Migration Studies 37.5 (2011): 681-99o.

23 Ulf Hannerz, 'Cosmopolitans and Locals in World Culture.' Theory, Culture and Society 7 (1990): 237-251.

24 David Pollock and Ruth Van Reken, The Third Culture Kid Experience: Growing Up Among Worlds. Yarmouth: Intercultural Press, 1999. 
Furthermore, we find Homi Bhabha's idea of a 'third space'25 inspiring. But again, Bhabha's in-betweenness does not fully capture the experience of our respondents. Instead of the postcolonial identity politics identified by Bhabha, we observe a conscious maintenance of a life marked by living in a tension of 'in-betweenness' from a position of relative privilege (China) or only subtle power differentials (Northern Europe).

The in-betweenness we observe evolves in a non-linear process with unexpected twists and turns, partly as a result of an individualizing, and mobile world, partly influenced by biographical events. However, our respondents do not only react to influences. Instead their relative affluence provides them with (mobility) options and thus with the agency to decide whether, when and where to move on in their lives. Often, there is a backup plan, or at least the possibility to return to the 'safe haven' of Switzerland.

To sum up, the third positions we came across in our ethnographic research need further reflection and conceptualization. The point of departure could be the notion of in-betweenness of rather affluent, and mobile subjects, which results in often consciously chosen, and mainly fulfilling lifestyles but also entails feelings of vulnerability, and sometimes loneliness.

\section{Bibliography}

Appadurai, Arjun. 'Disjuncture and Cultural Difference in the Global Cultural Economy.' Theory, Culture and Society 7 (1990): 295-310.

Bhabha, Homi K. The Location of Culture. London: Routledge, 1994.

Cohen, Scott A., Tara Duncan, Maria Thulemark. 'Lifestyle Mobilites: The Crossroads of Travel, Leisure and Migration.' Mobilities Vol. 10/1 (2015): 155-172.

Elliott, Anthony and John Urry. Mobile Lives. Oxon: Routledge, 2010.

Farrer, James. "New Shanghailanders" or "New Shanghainese": Western Expatriates' Narratives of Emplacement in Shanghai.' Journal of Ethnic and Migration Studies 36/8 (2010): 1211-1228.

Fechter, Anne-Meike. 'The 'Other' Stares Back. Experiencing Whiteness in Jakarta.' Ethnography 6/1 (2005): 87-103.

Glick Schiller, Nina, Linda Basch, Cristina Szanton Blanc. 'From Immigrant to Transmigrant: Theorizing Transnational Migration.' Anthropological Quarterly 68/1 (1995): 48-63. 
Guarnizo, Luis E. and Michael P. Smith. 'The Locations of Transnationalism.' Transnationalism from Below. Edited by Michael P. Smith and Luis E. Guarnizo. London: Transaction Publisher (1998): 3-34.

Hannerz, Ulf. 'Cosmopolitans and Locals in World Culture.' Theory, Culture and Society 7 (1990): 237-251.

Heller, Monika. Paths to Post-Nationalism. A Critical Ethnography of Language and Identity. Oxford: University Press Inc, 2011.

Lan, Pei-Chia. 'White Privilege, Language Capital and Cultural Ghettoisation: Western High-Skilled Migrants in Taiwan.' Journal of Ethnic and Migration Studies 37/10 (2011): 1169-1963.

Mahler, Sarah J. 'Theoretical and Empirical Contributions Toward a Research Agenda for Transnationalism.' Transnationalism from Below. Edited by Michael P. Smith and Luis E. Guarnizo. London: Transaction Publisher (1998): 64-102.

Pieke, Frank N. 'Immigrant China.' Modern China 38/1 (2012): 40-77.

Pollock, David, Ruth Van Reken. The Third Culture Kid Experience: Growing Up Among Worlds. Yarmouth: Intercultural Press, 1999.

King, Russell. 'Towards a New Map of European Migration.' International Journal of Population Geography 8 (2002): 89-106.

Salazar, Noel B. 'The Power of Imagination in Transnational Mobilities.' Identities: Global Studies in Culture and Power, 18/6 (2011): 576-98.

Sklair, Leslie. The Transnational Capitalist Class. London: Blackwell, 2001.

Yeoh, Brenda S. A., Shirlena Huang. 'Introduction: Fluidity and Friction in Talent Migration.' Journal of Ethnic and Migration Studies 37/5 (2011): 681-99o.

Vertovec, Steven. Transnationalism. Abingdon: Routledge, 2009. 